\title{
The Trauma of Goodness \\ in Patricia Grace's Fiction
}

Irene Visser

$I_{t}$ is a time-honored tradition among non-Māori academic critics and researchers in the field of Māori studies to reflect explicitly on their position in relation to Māori culture and literature. In the early years of the twentieth century, Elsdon Best, seen by his contemporaries as the "greatest living authority on the Māori both nationally and internationally," apologized for the Eurocentrism (as it would now be called) of his Pākehā colleagues in the field and expressed hope for a time that had not yet come, a time "when man becomes more altruistic, and recognizes primary truths outside national, racial and sectarian limits" (I922, 9). Since then, aided by the influence of postcolonial studies, general awareness of the need for a respectful and more "altruistic" research climate has increased, but in the field of Māori studies, the explicit positioning of oneself in relation to the area of research has not become redundant, as for instance was observed by analytic philosopher John Patterson in his I 992 study of Māori ethics. Patterson presented his work from the position that such an exploration would be unwelcome if it were meant to "unilaterally set the terms of reference for the Māori-Pākehā interactions," and he cautioned against such an attitude, which in the past was often "a prelude to plunder and colonization" (I992, IO).

In the new millennium, Eva Rask Knudsen's important study of Australian Aboriginal and New Zealand Māori literature, The Circle and the Spiral, likewise emphatically cautions against what it calls the "unreflective appropriation of indigenous writing within the academy" (2004, xii). Writing this article in $20 \mathrm{II}$, and as a Dutch academic working in the field of contemporary literary studies, I align myself with these culturally sensitive positions, confirming the ongoing need for a respectful and open-minded receptiveness to Māori literature. Like Knudsen, I am aware

The Contemporary Pacific, Volume 24, Number 2, 297-32I

(C) 2012 by University of Hawai'i Press 
of Eurocentric trends in postcolonial literary studies, and in this article I am particularly critical of certain aspects of cultural trauma theory that hinder or limit a critical engagement with Patricia Grace's depiction of trauma in her fiction.

The call for reflection and caution in the engagement with Māori culture and history is a constant throughout Patricia Grace's work. Her novel Baby No-Eyes denounces the practices of Western academic and scientific appropriation of Māori knowledge and identity in no uncertain terms, equating the imperial practice of land expropriation (the "old business" of taking land) with late twentieth-century genetic research among Māori (the "new business" of taking eyes to collect indigenous genes). The novel's critique, as expressed in the bitter words of Māori spokesman Mahaki, is that " $[\mathrm{t}] \mathrm{o}$ come from a background of being white, Christian and so-called 'civilised', was to be right; was to have the power of law and state and wealth, a certain way of thinking and feeling on your side" (Grace I998, I22).

In the field of trauma theory, similar charges of hegemonic attitudes have been raised against Western critics. Models of trauma based on Freudian psychoanalysis and focused on individual psychological processes have been found inadequate by postcolonial critics working with trauma literature (Collins 20I I; Miller 2008; Whitehead 2008). In real-life circumstances, moreover, AIDS workers and trauma therapists working in nonWestern conflict areas have voiced their concerns about the ethnocentrism of imposing the Western trauma model in these areas (Bracken and Patty I998). Despite these negative critiques, a growing number of publications in postcolonial literary studies draw on concepts from cultural trauma theory, contributing to what Roger Luckhurst has termed the "rise and rise" of this theory $(2008,2 \mathrm{I} 2)$. It is important to note that trauma studies as an interdisciplinary area of research is a hugely extensive field involving a broad range of specializations and that in this field there is no single "trauma theory" that is recognized as authoritative in all the disciplines that make up academic trauma studies, including law, history, sociology, psychology, cultural studies, and so forth. In this article, I engage with the dominant trauma theory in literary and cultural studies, which make up a fairly small part of this extensive field. This currently dominant cultural trauma theory was first formulated in publications by scholars from the Yale School in the I990s. Cathy Caruth's edited collection Trauma: Explorations in Memory (1995) and her essays in Unclaimed Experience: Trauma, Narrative, and History (1996) still constitute the cornerstones 
of cultural trauma theory today, despite the existence of opposing, more therapeutically and sociologically oriented strands in trauma studies that offer alternatives to Caruth's emphasis on aporia, the impossibility of knowing and narrating trauma. Writers that have published genealogies of trauma, such as Ruth Leys (2000) and Roger Luckhurst (2008), concur that despite its influential position in literary studies, Caruth's cultural trauma theory has serious limitations. Of the various limitations to the theory that Leys and Luckhurst have pointed out, I would argue that the depoliticizing and dehistoricizing tendencies of trauma theory are the most serious from the perspective of postcolonial criticism. Trauma theory, as Luckhurst stated, "shockingly fails to address atrocity, genocide and war" and because of this, "notions of 'cultural trauma' might block pathways to practical politics" (2008, 2I3).

This article addresses the question of whether cultural trauma theory in its present dominant form in literary studies is adequate for the discussion of trauma in postcolonial writing, where trauma is incurred by prolonged, cumulative, and chronic experiences of injustice and repression in specific historical contexts. In Māori literature, and in Patricia Grace's work in particular, trauma cannot be understood in isolation from the context of sociohistorical causes and present-day political effects. Because Caruth's cultural trauma theory is increasingly drawn on in postcolonial criticism, there is an ongoing need to carefully scrutinize and question its tenets, particularly since the discussion about the possibility of a postcolonial or decolonized trauma theory continues to be relevant (Najita 2006; Rothberg 2008; Visser 20II). As Susan Najita stated in Decolonizing Cultures in the Pacific, "The problematic of trauma-the question of what one does with it-becomes a fundamental process of decolonizing the nation" (2006, I9). My aim in this article is twofold: (I) to contribute to this discussion as well as to the critical understanding of Patricia Grace's fiction by exploring the meanings of the central theme of traumatic "goodness" in her novels of the I980s and I990s, and (2) to reflect on the expository potential of cultural trauma theory and its limitations in this critical praxis.

\section{Grace And Goodness}

It is today no longer necessary to introduce Patricia Grace as one of the foremost authors of New Zealand literature. With Witi Ihimaera and Hone Tuwhare, she was among the first authors to publish Māori litera- 
ture in English following the Māori Renaissance of the I970s. Grace's fiction has been internationally acclaimed and has received specific recognition for its depiction of Māori culture and philosophy in historical and contemporary contexts. Her work, particularly the novels of the I970s through the I990s, has been seen as groundbreaking and as heralding "a significant shift in New Zealand's literary tradition, from its Eurocentric foundations to a postcolonial perspective that privileges the 'insider' or indigenous point of view" (Romaine 2004, 32). In an interview Grace confirmed that her writerly project has a political side to it, to give voice to the politically marginalized in her country: "You're few in numbers, in your own country and through the political and the social events that have happened in the country the small group has become powerless, if you are writing about those people in their powerlessness, whether you do it deliberately or not, the writing is political" (Calleja 2003, I I3). Critics have recognized the centrality of this political agenda in Grace's writing. Chris Prentice, for instance, stated that what Grace demonstrates in her work is the continuing colonization of the Māori, expressed in cultural concerns directly related to land and embodiment: "Land and bodies figure as sites of colonial expropriation, exploitation, and violence" (Prentice 2009, 322).

While Aotearoa/New Zealand gained political independence from Britain in 1907, the imprint of colonialism is a continuing influence after decolonization. Settler colonies such as Aotearoa/New Zealand and Australia have been described as both colonial and postcolonial "in that their settler populations have achieved political autonomy from Britain, while continuing to exercise political and cultural hegemony over the Indigenous aboriginal and Māori populations" (Keown 2007, 24). During the period of circa I920-1970, the time frame in which the three novels by Patricia Grace discussed in this essay are set, there were no equal success rates between Māori and Pākehā New Zealanders in the areas of employment, health, and education. Statistics demonstrate inequality in average life expectancy, suicide rates, substance abuse, and criminality. In Grace's novel Potiki, a reference to this demographic situation can be seen in the child Toko's reflection on what he imagines is the perspective of the Pākehā land developer: "I saw what he saw . . . a brokenness, a broken race. He saw in my Granny, in Mary and me, a whole people, decrepit, deranged, deformed" (1986, I02). Holly Walker stated that despite economic development in the I990s, in the new millennium "there is no question that the majority of Maori are in a far worse socio-economic position 
than most non-Maori in New Zealand. Maori have higher rates of infant mortality, cancer, heart disease, crime, welfare dependency and incarceration, and correspondingly lower levels of life expectancy, average income and educational attainment" $(2005,2 \mathrm{I} 8)$. Taking stock of the position of Māori today, Margaret Mutu emphasized the continuing repressive force of Pākehā hegemony in its "retention of control of the country's resources, wealth, and privilege in Pākehā hands" (20I I, 227).

Patricia Grace's use of the concept of goodness in her novels must be read in this context of the history of the Māori as a repressed minority. Goodness as a concept in its usual meaning is positive, beneficial, and conducive to health and happiness, but in Grace's novels goodness takes on an entirely opposite meaning. Under the duress of systematic discrimination and repression by state institutions, goodness in its common meanings of goodwill and acquiescence becomes a compromised goodness. Grace's novels dramatize how under Pākehā hegemony, goodness turns into its opposite and becomes an evil, malignant, and even life-threatening force. It is an arresting aspect of Grace's use of the term that "goodness" in this antonymous use is not printed in inverted commas (ie, quotation marks). This usage avoids an ironic distancing effect and maintains the shock effect and the seriousness of the repressive use of the term that her fiction dramatizes. To maintain this effect, and out of respect for Grace's intentions, in this essay I also use goodness without inverted commas whenever its duplicitous meaning is evident. Goodness, as a legacy of the colonial situation, is revealed as a trauma: a poisonous force that undermines, weakens, and even destroys life. Grace's scrutiny of this traumatic goodness finds its most concentrated expression in three novels published between 1986 and I998. Potiki and Cousins present the wounding of children and its impact on the lives of adults and their communities. In Baby No-Eyes this process is dramatized most poignantly in narratives that confront the memory of the paradoxical imprint of goodness-as-evil.

In Grace's fiction, the trauma of goodness, which leaves as its aftermath an insidious "nervous condition," is incurred in the settings of school, orphanage, and hospital-institutions normally associated with care rather than wounding. This paradox is central to Grace's depiction of the trauma of goodness, in which the lives of Mãori children in the second half of the twentieth century are affected by the colonial contradictions between education and repression, care and wounding. In primary school settings, the concept of goodness is contaminated to the extent that it becomes indistinguishable from evil, not only in its guise as good behavior 
that is inimical to children's cultural and racial identity, but also in the children's felt sense of self. "How difficult it is," as one of Grace's characters says, "to learn that you are evil when you thought yourself good" (1998, 65).

\section{The Goodness of School Children}

Potiki, Grace's first novel to explicitly address the theme of goodness in the setting of an educational institution, does not at first problematize the concept of goodness but presents it primarily in its usual expression of "whatever is good in itself, or beneficial in effect." 1 Thus the word "good" is used to refer to the child Mary Tamihana, Hemi's "retarded sister," who "was someone to love ... she was good and that goodness should have love and care" (I986, I6). As a little girl, Mary is protected by her friend Roimata, and since she is given suitable tasks to do at school, she remains largely unaffected by the school's indoctrination of subservience and inferiority. Mary's story therefore presents a milder portrait of the educational regime than do the subsequent micronarratives featuring similarly vulnerable child characters, such as Manu and Toko, whose special needs are not met at school and who are therefore homeschooled. As the novel progresses, Potiki situates the educational system in the wider context of hegemonic repression by governmental agencies and land developers, making the racial repression inherent in the school system a central issue in the lives of Māori adults and children. Hemi Tamihana recalls bitter memories of his schooldays, speaking of his generation as follows: "their ancestors had been rubbished in schools, and in books, and everywhere. So were their customs, so was their language ... it was an attack on you, on a whole people" (1986, 65). Reuben, representing the contemporary generation, is equally bitter in describing the racism of the media and of his school's teaching, which brands him as inherently bad: “That's all I learn at school-that I'm not somebody, that my ancestors were rubbish and that I'm rubbish too. That's all I learn from the newspapers, that I'm nobody, or I'm bad and I belong in jail . . . it makes us dumb, it puts us wrong" (I986, 74-75).

The trauma presented by Grace in these speeches is the continuing psychological wounding not only of individuals but also of several generations of Māori children. Trauma, according to the first official definition by the American Psychiatric Association in I980 (APA-TFNS I980), is to be understood as a serious injury or threat to the physical integrity of the 
self; it is an overwhelming, sudden, and unassimilable experience. The metaphor of trauma often used in trauma theory is that of a sudden, sharp piercing of a membrane-for instance by a sharp object that remains implanted in the psyche in its original form, hidden behind the screen of consciousness but making itself known through a serious of symptoms. The "sudden" or unexpected aspect of trauma is not the same as the chronic, cumulative hurt of long years of repression as narrated in Grace's fiction; nevertheless, the wounding of one's sense of identity during the childhood years is indubitably a traumatization through its aftermath in personal distress. This is in accordance with the notion in trauma theory that "trauma" in fact refers not so much to the traumatic event itself as to the post-traumatic phase.

Trauma, then, is the painful recurrence of the traumatic experience through various symptoms (such as nightmares and flashbacks) that fall under the definition of Post-Traumatic Stress Disorder (PTSD). As formulated in 1980 by the American Psychiatric Association, PTSD is the basic framework for understanding the effects of trauma, which are extremely diverse, including symptoms such as depression and emotional numbness but also increased sensitivity and emotional excitability. The stigma of Māori "badness" imprinted on children at school and in the media may be understood as a long-term and widespread traumatization, whose symptoms can be as diverse as those categorized under PTSD. Of these, Grace's fiction poignantly depicts depersonalization and loss of self-esteem. Grace's novels moreover emphasize that the indoctrination of social inferiority leaves this aftermath of traumatic memory as a burden not only to individuals but also to their communities.

Religious references are part of the disciplinary structures of the Catholic school system that Grace's novels illustrate, and they contribute to the undermining of children's cultural identity formation. Divine authority is typically invoked to enforce discipline. In Potiki, Romata recounts, "It was God's will for us to sit still . . . that we wear aprons, bring pennies for souls, eat our crusts ... that we sing the alphabet, the multiplication table" (Grace I986, I6). The novel Cousins continues Grace's depiction of the damaging influence of a religiously inflected pedagogy on vulnerable children, by portraying Mata, a child kept "good" and isolated from the supportive circle of the extended family.

Cousins presents the life stories of three cousins, each educated under different circumstances and with different experiences of both Māori and Pākehā school cultures. Grace's interrogation of the impact of the discrim- 
inatory school system, begun in Potiki, continues here with the opening story of Mata Paraima, daughter of a Māori mother and Pākehā father, who grows up in a Catholic orphanage called "The Home" in Mata's narrative. Referred to as May Palmer by her Pākehā teachers, the child is taught that she can be good if she denies and rejects her Māori background (which is "bad" and "evil"). But at the same time, she learns that she is irrevocably "bad" precisely because of her Māori blood and that her teachers' challenge is to erase all traces of her background— "to make good from bad" (I993, 8I). Mata is kept away from her relatives, and thus from evil and $\sin (1993,72)$. In this Catholic institution of care (the only "Home" she knows), a constant sense of guilt, sin, and shame is imposed on Mata as inherent in her race and expressed in the "bad" Māori language, hair, and skin. Being instructed to attempt to be good-that is, to resemble the Pākehā children-she is at the same time indoctrinated with the conviction that she cannot ever be good. This is an existential paradox exemplified by the image of Mata's "bad" black curls, which should, impossibly, resemble Betty's "good" blond curls.

The caring and nurturing extended to the children in the orphanage and its school are accompanied by racist repression, a paradoxical mixture whose effects constitute the trauma of goodness in Grace's fiction. These effects are devastating. After leaving the Home, Mata leads a life of quiet misery for thirty years, being "good" in the sense of being fully estranged from her Māori relatives. Capable only of "waiting and wanting," as she describes it, Mata displays the numbness characteristic of trauma victims. Her childhood traumatization spreads into her later life as an inverted violence, an imprisonment enacted by herself as an extension of the repression by the Home. Hidden from conscious awareness, the trauma of Mata's early years remains for decades an inescapable and crippling condition whose healing seems impossible. Not having learned the customs and culture of her Māori whanau (extended family), hapū (clan or subtribe), and iwi (tribe), Mata does not have a sense of self sustained by her culture; she only knows that she is Mata Paraima instead of May Palmer. Due to the trauma of goodness, she remains sealed within herself, living her life in a near-comatose state for thirty years, estranged from Māoritanga (Māori culture) and from herself, and also leaving her hapū bereft of one of its members. Here, as in the two other novels, Grace has posed that goodness, in the hands of the educational system, becomes an invidious and contorted concept, part of the trauma of the postcolonial subject whose effects spread to the entire community. 


\section{Trauma Theory: Belatedness and Melancholia}

Trauma theory offers various insights into the traumatic condition depicted in the character of Mata. Her long years of inertia and melancholia may be understood within the theoretical framework of trauma theory as displaying the belatedness typical of trauma, Freud's notion of Nachträglichkeit. This describes the delayed recurrence of the traumatic experience in conscious awareness, which often defies exact knowing and may remain inaccessible to narrative or conscious thought. This latter notion of the "unspeakability" of trauma is a central tenet of cultural trauma theory. As Caruth stated, the nature of the traumatic experience is that "the most direct seeing of a violent event may occur as an absolute inability to know it; that immediacy, paradoxically, may take the form of belatedness" (I996, 9I-92). This accurately reflects Grace's depiction in Cousins of Mata's inability to verbalize her condition of numbness that is the effect of her childhood years of chronic and cumulative psychological violence. It is the notable force of Grace's fiction that it allows an empathetic understanding of the profoundly crippling implications of the wounds of Mata's childhood and that its narrative representation at the same time conveys the emotional impact of the inhumanity of the postcolonial educational system.

While Freud's concept of Nachträglichkeit usefully illuminates the belated and crippling effect of trauma, Caruth has emphasized trauma's "unspeakability"-the aporia or ultimate impossibility of narrativization of trauma. Trauma, she stated, cannot be known or made conscious; it is an impossible condition that cannot be narrativized or made accessible to conscious knowing (Caruth I996). This notion, I claim, presents a constraint to the critical interpretation of fiction that, like Grace's novels, astutely dramatizes the narrative representation and interpretation of trauma. The resolution of Mata's traumatic paralysis presented in Cousins contradicts cultural trauma theory's tenet of unspeakability and its related notion of the impossibility of understanding and healing. Despite the severity and long duration of Mata's traumatic condition, she eventually returns to psychic health, aided by the rituals and ceremonies of the tangihanga (funeral) on her family's marae (cultural center). As Ranginui Walker elucidated, the marae is the focal point of Mãori culture and communal activities, the place where rituals and ceremonies are performed: "Essentially, a marae, with its ancestral house as the focal point, is the property of a kin group such as a hapu (subtribe) or an iwi (tribe)"; thus, 
"it is important for families to return the bodies of deceased kin to their home marae for the tangi" (I992, 20-23). In the novel's closing chapter, Mata recounts the curative effect of the tangi, her reunion with her kin group, and her homecoming to the rituals of her cultural background.

Mata's healing from trauma, then, is enabled by the whanau's gathering on the marae and the cultural expression of the spiritual values of her kin group. Writing about Māori women's role during the funeral ceremony, Joan Metge explained that "by the end of the tangihanga, they are emotionally and physically exhausted, but, purged of grief and actively encouraged by their kin, they are usually able to take up the threads of life again" $(1976,264)$. Metge also pointed out the absorption of culture that is facilitated by the "emotionally charged atmosphere of the tangihanga" and that is vitally important for identity formation (1976, 264). This is fictionally dramatized in Cousins by Mata's return to a sense of selfhood under the emotionally charged proceedings on the marae. Marae are symbolic statements of identity: "The marae is an institution where any Maori has turangawaewae, standing, in relation to the dominant culture of the Pākehā" (Walker I992, 26). Mata's recovery of selfhood from her long trauma of separation, loneliness, and low self-esteem is enabled by the therapeutic power of the communal rituals. When Mata hears the ceremonial opening invitation being chanted on the marae, she senses that "something is happening to her"- a phrase that is repeated several times. She finds release in crying, the tears seeming "to come from an unfound place, from years" (Grace 1993, 255). The narrative thus clearly conveys Mata's return to psychological health, aided by the therapeutic effect of the communal ceremony. The ritual's function is to enable the working through of grief and mourning in the realization that the dead are not erased from existence but, on the contrary, are fully part of the experience of the living. Under its influence, Mata too becomes fully part of the living circle of her family; her melancholia is cured and her trauma is healed as she is restored to her whanau and to herself.

Grace's fiction thus offers an alternative to cultural trauma theory's emphasis on aporia, the impossibility of seeking causes, remedies, and meanings for the traumatic condition. It also opposes the implication that melancholia is to be regarded as a lasting and defining condition of trauma. As Luckhurst stated, cultural trauma theory holds out "a kind of injunction to maintain the post-traumatic condition. To be in a frozen or suspended afterwards, it seems to be assumed, is the only proper ethical response to trauma," and by this reasoning, memory is situated "entirely 
under the sign of post-traumatic melancholia" (Luckhurst 2008, 210). This emphasis on melancholia would deny Grace's claim to the healing effect of indigenous ceremonies and to the resilience that Grace portrays, even in the life story of a severely traumatized character such as Mata. Various literary critics in recent years have seen the emphasis on melancholia as limiting the usefulness of trauma theory in postcolonial literary studies (Rothberg 2008; Whitehead 2008; Park Sorensen 2010). Knudsen, while not specifically addressing trauma theory, expressed this critical stance by objecting to theoretical readings that reduce the "vigour and imaginative impact" of postcolonial literature by making the postcolonial condition "sound like a serious ailment when in fact it has given birth to strong-lived visions of cultural recuperations" (2004, I I). While cultural trauma theory offers valuable insights into the nature and workings of post-traumatic melancholia, its emphasis on melancholia as part of the irrevocable aftermath of trauma is limiting, and, I argue, inadequate for the reading of trauma in Potiki and Cousins, where victimization and melancholia are presented as effects of knowable causes and as stages in the aftermath of trauma rather than as trauma's defining and static condition.

\section{The Evil of Goodness}

Baby No-Eyes continues Grace's interrogation of hegemonic repression, injury, and eventual destruction of the selfhood of vulnerable schoolchildren and brings it to a conclusion. The novel draws attention to the peculiar nature of the traumatic memory of goodness in its arresting conflational use of the terms good and evil, in particular through the narrative of Gran Kura, a central voice in this polyphonic narrative. Kura's process of memory and narration is set in motion by the shockingly inhumane treatment in the hospital, where the dead body of their baby is returned to Kura and her family without her eyes. This scene, as Grace explained in an interview, was based on an actual occurrence (Calleja 2003, I I 7). In this encounter, Kura awakens to the full realization of her own complicity. This painful moment occurs only after Baby's eyes have been found and handed over in a supermarket bag and when the family has been told that they cannot take the baby's body home but must wait for police permission. Kura mechanically agrees. Only then does she realize that this consent is a result of Pākehā indoctrination and a betrayal of her real feelings: "words coming out of me, coming from goodness" (Grace I998, 
65). Kura then equates good and evil for the first time, proclaiming her reaction as an "evil patience and goodness" and adding, "there I was, this evil woman. I began wailing for my sins" (Grace I998, 65). The hospital setting accentuates the inhumanity of the medical procedures and adds force to Kura's insight of evil parading as goodness and to her subsequent narrative of the traumatic legacy of the colonial system and its memories of shame, obedience, numbness, and complicity.

The impact of the encounter at the hospital is instrumental in opening up Kura's childhood memories of the death of Riripeti, her six-year-old cousin who died after a prolonged period of punishments and humiliation at school that were carried out under the ruthless discipline imposed by the school on Māori children. Riripeti, or Betty as she must be called at school, is always good in that she never disobeys or disrupts the school's classes, but she is repeatedly punished for not knowing enough English to understand the teacher. Goodness used by Grace in this context is already presented as harmful: "Riripeti was too good to guess what to say, too good to know what lies to tell, too good to know what to do" (I998, 33). After inadvertently speaking a few words in Māori, Riripeti is caned in front of the other children. As Kura recalls, "we all had to stand in our lines and watch this caning so we would learn how bad our language was" (Grace I998, 37). Made to stand in a corner for hours and called "an animal" by the teacher, five-year-old Riripeti finally loses her will to live and is, in Kura words, "killed by school. Dead of fear" (1998, 38 ).

In Kura's narrative, the trauma of the repressed memory resides not so much in the image of colonialist cruelty but in the realization of her own "goodness," which as a child made her accept the teacher's punishments as just. Blind to the inordinate cruelty of the punishment, at the time she agreed with the teacher's judgment, thinking "what an evil thing our language was to do that to my teina" (Grace I998, 37). In the context of trauma theory, Kura's experience is to be categorized as secondary trauma, the trauma incurred by witnesses or bystanders, which may entail the same symptoms as those of primary traumatization. Dissociation, which is one of these symptoms, blurs boundaries and leads to traumatic identification, not only with the perpetrator but also with the victim. As Kura recounts, "I became sick too, just like Riripeti. I think I nearly died too" (Grace I998, 38 ).

The precise nature of Kura's wounding must be understood from the recognition that language is a defining element of Māori identity. This is recognized by the Waitangi Tribunal's documents, which state that "holis- 
tic thinking, group development, family relationships and the spiritual dimensions of life" are specific to Māori culture and that "the language is the embodiment of the particular spiritual and mental concepts of the Maori” (1986, 25). As Tāmata Reedy, former Secretary of the Department of Māori affairs, stated in an official publication, "Language as a separate but integral part of Māoritanga is significant-it is not reflected to the same degree in Pākehā culture. Language, te reo Māori, is an asset in itself not merely a medium of communication. It is sufficient for me to say that it is inconceivable that Māori people can retain any measure of [their] identity without the language" (quoted in Kāretu I994, 223). Thus, the child Kura's vow never to speak Māori again, as it is the evil language that killed her little cousin, means in fact an outright rejection of her Māori identity in "good" acquiescence with Pākehā teaching. Kura revokes this vow only after sixty years, that is, after the traumatic memories have been brought to light and worked through in narrative.

\section{The Transmission of Trauma}

Grace's presentation of collective trauma is predicated on the wounding of children's sense of self and on the repercussions of this wounding for their communities, not only at the time of the injury but also, as in Mata's and Kura's narratives, in later decades. "They were the beaten, the hollowedout of our people, the rawakore, the truly disinherited, where nothing substantial was inbuilt and nothing was valued or marvellous-where there was no memory, where the void had been defiled by an inrushing of anger and weeping. No one had loved their hair" (Grace I993, 208). This fragment from Cousins explicitly poses the connection between collective and individual traumatization by referring to Mata's internalized notion of "bad" Māori hair, pointing out that individual trauma is shared by the community. This is a crucial element of the trauma of colonization. In Potiki, the character Toko observes: "I understood the years of hurt, sorrow, and enslavement that fisted within my granny Tamihana's heart. I understood, all at once, all the pain that she held inside her small and gentle self. And the pain belonged to all of us. I understood that too" (Grace 1986, I02). The significance of this theme is again foregrounded in Baby No-Eyes, where Kura's narrative likewise emphasizes that individual trauma becomes communal, chronic, and crippling: "My heart broke for my teina. Oh I cried. She was mine, she was me, she was all of us. She was the one who had died but we were the ones affected, our shame taking 
generations to become our anger and our madness ... What an evil girl I was to let her die" (Grace I998, 38).

In cultural trauma theory, trauma is recognized as a force that undermines and weakens collective cohesion, constituting "a blow to the basic tissues of social life that damages the bonds attaching people together and impairs the prevailing sense of communality" (Erikson I99I, 47I). While the theory thus apparently illuminates the collectivity of trauma depicted in Grace's novels, it is questionable whether its foundational Freudian model of trauma adequately offers insights into communal processes.

To explain this, it is necessary to turn to Freud's thinking about collective trauma, the foundation of Caruth's influential publications in the field of cultural trauma theory. In Unclaimed Experience, Caruth stated that history is to be regarded as no longer based on "simple models of experience and reference" (I996, I I). Instead, she assumed an indirect referentiality, aligning herself with Freud's "political and cultural disengagement" as the basis of her re-presentation of Freud's "discovery" of the historical trauma of the Jews, namely their murder of Moses, forgotten as a guilty secret but preserved in memory, and in its latency becoming "fully known in another time and place" (I996, I6-I8). Caruth argued that Freud's account of Jewish collective racial memory of guilt and traumatic secret in Moses and Monotheism (1939) can "help us understand our own catastrophic era" (I996, I2). While this chapter of Caruth's Unclaimed Experience has been widely quoted, it has also aroused negative reactions. Luckhurst, for instance, doubted the value of Moses and Monotheism for present theorization, stating that "largely ungrounded speculations such as this on prehistory were typical of Victorian anthropology" (2008, 10). Ruth Leys argued that Caruth misread Freud's text by partially quoting passages and omitting crucial phrases in what Leys termed "glaring alterations" $(2000,282)$. For the present discussion of Grace's work, it is important to understand that Caruth's emphasis on the new perspective on history is predicated on the dissolution of historical factuality and that she in fact foregrounded an atemporal human (universal) trauma similar to Freud's phylogenetic theory. In the dialogue with Grace's fiction, this transgenerational, psycho-historical, timeless model of trauma cannot be adequate, I argue, because it denies the significance of the historical particularity of the traumatic event that is crucial in Grace's fiction. While Grace's fiction presents the "brokenness" of Māori communities in Pākehā eyes, it also looks beyond it to seek its causes and to bring them to light, centrally opposing the aporetic claims of cultural trauma theory 
by posing that narrativization leads to understanding and resolution of trauma.

\section{Kura's Genealogy of Trauma}

In Kura's narrative, Riripeti's death at the hands of the schoolteacher becomes a story never spoken of, "our secret and our shame" (Grace I998, 63). Kura thus emphatically places the trauma of goodness within the life of the community, where it is a "sickness" affecting all members. She realizes that her own goodness, too, has had this effect: "You hold yourself back, and by doing that you hold back others ... How evil it is to be so good" (Grace I998, 63). Kura traces the origin of evil/goodness back to the first decades of colonization in order to reveal its full nature and, as she states, in order to end it and protect later generations. Storytelling thus is presented as a curative force. The genealogy starts in the midnineteenth century when colonization made goodness into a "sickness" and a "stealing from the children" (Grace I998, I07). Tumanako, Kura's great-grandfather, the "birdnosed one," was unaware that by cooperating with the colonial powers, the Māori would be robbed; "he didn't know that goodness was a thief" (Grace 1998, I07). We must note that Grace here has used the word "goodness" consistently in its negative connotation as submission and compliance. Trusting goodness, Tumanako allowed the loss of property and the "thieving" from later generations. To these generations, the loss of land was debilitating and shameful: "They lived in poverty and sickness and peace. Goodness and silence had set itself in amongst the people ... to become stories of shame" (Grace I998, I I6). Goodness caused conflict and strife within the community: "It was after Tumanako's death that goodness and obedience turned us against ourselves. Individuals began to apply to the courts for land to be broken up into further separate titles because that's how it was done in the new law" (Grace I998, I I6). Goodness as peaceful cooperation with the colonizer proved profoundly damaging to the health of the community. Kura's interrogation of guilt and complicity does not spare the Māori elders involved: "They had stolen their grandchildren's lives" (Grace I998, I I6). This history of compliance with the governments' repression continues well into the twentieth century, deepening the trauma of loss and impoverishment.

For much of the twentieth century, assimilation was the official political ideology in New Zealand, and as Grace's fiction dramatizes, it was 
imposed on Māori parents, who had to accept its implementation through strict disciplinary methods in the school system. Kura remembers taking pride in this cooperative attitude: "We were known as a good family. I'm not saying that to be boastful" (Grace I998, 37-38). Kura explains that Māori parents' apparent endorsement of hegemonic ideology sprang from their desire to protect the children when it was understood that being "good" meant being safe: "We don't want our children to be hurt at school. That's why you have to be very good. You have to listen, you have to obey" (Grace I998, 30). In an interview, Grace reinforced this view, making Kura's words her own: "They suffered a lot of poverty, a lot of deprivation and they always had to be 'good' so that they could survive, not to do things that would get them into trouble. They did not want to speak out" (quoted in Calleja 2003, I I 8).

Under the policy of assimilation, the general notion was that the English language was the key to success for Māori children. This historical development started in 1905 with the injunction of the Inspector of Native Schools to school principals to encourage Māori children to speak English on the school grounds. As Ranginui Walker stated, this "rapidly translated into a general prohibition of the Maori language within school precincts," which lasted for more than fifty years and was indeed in some cases reinforced by corporal punishment (2004, I74). This educational policy had a long-lasting and repressive effect: "Schooling has had a devastating impact on Māori language. The moves to ban Māori from school grounds because it limited children's learning potential was followed closely by exhortations to Māori parents that they would best help their children by not using Māori at home either. School policies were reinforced by widely held Pākehā beliefs that Māori language consisted merely of gesticulations and superficial greetings and was linguistically and semantically incapable of handling the complex concepts and skills needed in a school programme. Unfortunately, this ideology has been internalised by many Maori as well" (Smith I993, 2I8).

The long aftereffects of this "goodness" (Grace's term) are fictionally presented in Baby No-Eyes in Kura's acceptance of Riripeti's harsh punishment, which continues as a festering traumatic memory. Kura realizes that for sixty years she has endorsed the policies of the government that were meant to erase Māori identity, "trying and trying not to be who we were. When we put makeup on our faces it was to cover the colour, to cover the ugly, cover the bad. We really meant it. We didn't want to be 
these bad, ugly people, speaking this heathen language. We wanted instead to be these good people, wanted our children not to be who they were" (Grace I998, I47-I48). This fragment movingly evokes Māori parents' dilemmas in the historical period that the novels cover. A language survey taken in 1970 demonstrated that most native speakers of Māori were over thirty years of age, and only approximately 2 percent of children spoke Māori as a first language (Keown 2007, I63). By the same token, Gran Kura's language activism and her teaching of Māori at primary school accurately reflect historical events in New Zealand in the late I970s, after the assimilation policy had ended under the influence of the Mãori Renaissance and was changed into a politics of identity and of cultural diversity. Under these new conditions, speakers of Māori were often encouraged to help with language teaching at primary schools. Kura's name resembles the name of the alternative educational program that was developed in the I980s and became official policy in I989, the "Kura Kaupapa Māori," which "articulates a philosophy which has its foundations in the past but its hopes in the future. It has set out to make 'being Māori' the norm and seeks to instill in its children the knowledge and skills that they will require to live as well-educated adults in a world which for them will always be essentially Māori” (Smith I993, 22 I-222).

Cultural trauma theory would need to be expanded to enable interrogations of the complex workings of trauma on the processes of self-construction in postcolonial contexts in which complicity, guilt, and agency are crucial issues. Such a self-critical scrutiny of complicity is enacted by Kura in Baby No-Eyes as part of the working through of trauma toward health. However, the complicated entanglement of guilt, complicity, and revenge is not at present a dominant focus in trauma theory. The dominant focus is on the empathic, other-oriented ethos of trauma theory as articulated by Shoshana Felman and Dori Laub (1992), who, like Caruth, have been authoritative voices in trauma theory since the early r990s. While this ethos is unquestionably valuable in actual therapeutic situations and in classroom discussions of trauma narratives, for a postcolonial trauma theory, the complexity of psychological processes dramatized by Grace invites a new positioning. Grace's fictional presentation of trauma offers an alternative to the dominant model, opening up trauma in relation to guilt and complicity, and, moreover, pointing out the limits of the dominant trauma model, which poses that trauma by its very nature resists a restoration of health and equilibrium. 


\section{Metaphors to Live By}

Grace's use of metaphors to evoke the nature of trauma is particularly illuminating in representing the debilitating nature of the traumatic aftermath but also in foregrounding the restorative impulse as an important aspect of the trauma of goodness. Besides the metaphor of protective camouflage urged by parents on their young children, the metaphors of goodness include that of a sickness that, once it has entered the body, will remain in the stomach for many years. Living with this sickness, a person can survive but is unable to live fully or to experience a fulfilled existence. Thus, the traumatic memory of Riripeti's death remained in Kura's stomach, we read, for sixty years. However, Grace's use of metaphors also emphasizes the restorative potential of trauma. In Baby No-Eyes, several metaphors of trauma are given besides camouflage and sickness, each displaying crucial facets of this potential.

The most prominent metaphor of trauma in Baby No-Eyes is that of a layer of windings, like bandages wrapped around a central core. Kura explains this as follows: "I had practised and practised goodness until I believed my camouflage was me-but somewhere down inside was the spirit, or a little core of it, bandaged round and round" (Grace I998, I07). The metaphor of bandages of "goodness" wrapped around the core of authentic or "wild" identity indicates that traumatic memories, however stifling and constricting, can be removed-a process indeed enacted by Kura's narrativization of the injustices done to her people as well as of their own complicity and shame. A further significant metaphor of trauma is used in the story of Kura's grandson Shane. Here, goodness is an unbearably heavy burden imposed on the young by older generations, which can, and indeed must, be thrown down and smashed. This is a direct, violent breaking of the bonds of trauma, much different from the slow removal of layers of pain. The two metaphors occur in one fragment of Kura's story, demonstrating the difference between the generations: "Shane . . . didn't know what to do about this goodness that kept hounding him. In the end he had to smash it at my feet in order to make my eyes spring open; in order to prise my lips apart; in order that I could be cured of my thieving ways and this goodness; in order that I could begin to unravel the sticky, twining cloths that kept wildness, like a hidden treasure, trapped within" (Grace I998, I07).

Surprisingly, the image of trauma here is not the sharp, sudden piercing of a membrane, but a burden to be violently cast aside and broken. This 
is a violence that leads to health: jolted into awareness, Kura understands that she must herself take action (by telling Riripeti's story, opposing the authorities, embracing political activism, and so on) in order to be healed: "It's only now I know what I should do because Riripeti died, or because of Shane and Baby. It's only now I can rid myself of this sickness, so that in the end I can have a healthy death. It'll come to you, you'll see" (Grace I998, I48). The metaphors of unwinding bandages, smashing heavy objects, and ridding oneself of sickness all convey the sense that trauma can be negotiated and resolved. Moreover, it is in fact the trauma of goodness itself that urges the process that leads to its healing.

In Baby No-Eyes, the ritual of Baby's burial helps her mother, Te Paania, to integrate the injustices of the hospital treatment and reinforces the healing process that results in Te Paania's return to her Māori relatives and her awakening to a political awareness. Te Paania's pain at hearing about her child's mutilation by the hospital staff is captured in the metaphor of a burning stone entering the body and moving to its center, "a hot stone which moved down through the bones of my face, hollowing and searing them. The burning stone dropped ... taking my heart to my stomach, where it broke and opened, reaching to every part of me" (Grace I998, 7I-72). The traumatic event here does not become a latent disorder but is integrated in Te Paania's awareness and body through the ritual words spoken by Gran Kura in Māori, the language that Te Paania does not herself speak. This may be seen as a manifestation of mana, the Māori concept denoting personal and communal standing that has its roots in both the secular and the spiritual world. Mana is a complex concept, and its meanings have changed through time. As Metge wrote, "in Classic Maori times, mana signified power of supernatural origin which possessed rather than was possessed by both men and things" (1976,63). While the concept is still extensively used, its meaning now includes social prestige and secular power. However, as Metge observed, "the word mana ... can almost always bear both interpretations," and its spiritual aspect remains in the sense that mana can be received from the ancestors $(1976,64)$. Maori Marsden, too, has viewed mana as a force that "brings a person into intimate relationship with the gods and his [or her] universe" (I992, I37). Te Paania's homecoming to Māoritanga and the mana that she receives on the marae prevent melancholia or any other traumatic "layering of bandages," empowering her to become a fully involved, resilient, and politically active member of the Māori community. 


\section{Recuperation and Redress: Concluding Remarks}

Cultural trauma theory holds that the exact nature of trauma cannot be known or expressed fully and that distortion occurs when we make trauma conscious through language. Grace's fiction, however, demonstrates that trauma can be narrated with integrity and that storytelling enables a healing process that allows insight, acceptance, and access to various modes of redress. Storytelling is a vital element in Grace's work; as Najita remarked, "the power of oral testimony and witnessing structures Patricia Grace's novels" (2006, I8I). The structure of Potiki is directly modeled on the whaikōrero (a piece of oratory), as Grace explained in an interview (Calleja 2003, I I 4). A decolonized reading of trauma involves the acknowledgment of the centrality of oral modes of narrative and their special position in indigenous community structures. Orality, as Najita observed, "provides a language to articulate a new mode of belonging based upon genealogy that leads out of and beyond the traumatic past" and even "through and out of colonization" (2006, 23). This view contrasts sharply with Caruth's notion that trauma necessarily resists or defies narrative and exegesis, which is still a core concept in cultural studies today; Tom Toremans, for instance, has called it the "landmark and constant point of reference" of cultural trauma theory (2003, 336).

Caruth's writings avoid engagement with the notion that narrative inquiry therapeutically illuminates the historical causes and social impact of traumatic memory and can lead to recovery. In claiming the "unsayable" (yet literal) causation of trauma and the aporia of narrative, cultural trauma theory therefore does not offer a framework for the understanding of the concrete, historical causation of trauma, and in this respect it proves inadequate in the interpretative engagement with Grace's fiction, where the sociohistorical factors of colonial oppression are central elements. Unspeakability, as a defining aspect of trauma, is indeed a crucial impediment to health, as demonstrated by Mata's lack of words and Kura's years of silence. However, as Baby No-Eyes demonstrates, the traumatic impediment to expression may itself become the condition that eventually urges expression and leads to release. Trauma may be understood as a disorder that can remain latent or dormant for nearly a lifetime but even then is not beyond healing once it is confronted and narrativized. Grace's fiction situates the curative effect of the engagement with trauma in close connection with political action as well as with the performance of ceremonial rites. 
In her novels, trauma is healed by the Mãori rituals of burial and communal mourning, situated in the context of Māori activism.

The curative contact with Māori ceremonies, the marae, the reo Māori, and the traditions honoring the ancestors is aided by the sacred power of storytelling. Storytelling means connecting the past and the present, drawing on the ancestors and their sacred power to restore harmony and health. This aspect of Grace's fiction elucidates a further limit of the trauma paradigm for postcolonial praxis. Indigenous concepts of spirituality, as Smith stated, "are critical sites of resistance for indigenous peoples. The values, attitudes, concepts, and language embedded in beliefs about spirituality represent, in many cases, the clearest contrast and mark of difference between indigenous peoples and the West" (1999, 74). The Western trauma model does not acknowledge spirituality as a cultural reference point; indeed cultural trauma theory's deconstructivist orientation denies the possibility of regeneration through ritual and belief systems. This justifies the conclusion that cultural trauma theory is inadequate for a reading of indigenous literature that, like Grace's fiction, seeks to explore trauma in the context of ritual and ceremony.

Grace's exploration of the trauma of goodness in three successive novels may be seen as in itself a recursive and healing process of storytelling, as the turning movement of the spiral, widening out from a central point in a movement in which elements are revisited and eventually a balance is found. In Potiki, Cousins, and Baby No-Eyes, Grace has developed a fictional exploration of the insidious effects of Pākehā education on Māori children, resulting in the trauma of goodness incurred by primary as well as secondary victims, but also eventually finding closure and regeneration in the social life and healing rituals of Māori culture. Māori traditions and ceremonies, and the particular healing powers of oral storytelling, are instrumental in bringing about the processes of reconfiguration of identity that Grace's characters successfully accomplish. Since cultural trauma theory does not offer a conceptualization of these processes, I would conclude that a reconfiguration of cultural trauma theory's central tenets must take place before it can be usefully integrated in postcolonial literary studies.

\section{Note}

I Oxford English Dictionary Online, under the word "goodness," http:// www.oed.com/view/Entry/79973? rskey=xfHTeL\&result= I \&isAdvanced=false [accessed 22 December 20II]. 


\section{References}

APA-TFns, American Psychiatric Association, Task Force on Nomenclature and Statistics

I980 Diagnostic and Statistical Manual of Mental Disorders. 3 rd edition. Washington DC: American Psychiatric Association.

Best, Elsdon

I922 Some Aspects of Maori Myth and Religion: Illustrating the Mentality of the Maori and His Mythopeoetic Concepts. Wellington, NZ: The Dominion Museum.

Bracken, Patrick J, and Celia Patty, editors

I998 Rethinking the Trauma of War. London: Free Association Books.

Calleja, Paloma Fresno

2003 An Interview with Patricia Grace. Atlantis 25 (I): I09-I 20.

Caruth, Cathy

I996 Unclaimed Experience: Trauma, Narrative, and History. Baltimore, MD: Johns Hopkins University Press.

Caruth, Cathy, editor

I995 Trauma: Explorations in Memory. Baltimore, MD: Johns Hopkins University Press.

Collins, Jo

20I I The Ethics and Aesthetics of Representing Trauma: The Textual Politics of Edwidge Danticat's The Dawn Breaker. The Journal of Post-

Erikson, Kai colonial Writing 47 (I): 5-I7.

I99I Notes on Trauma and Community. American Imago 48 (4): 455472.

Felman, Shoshana, and Dori Laub

I992 Testimony: Crises of Witnessing in Literature, Psychoanalysis, and History. New York: Routledge.

Freud, Sigmund

I939 Moses and Monotheism. New York: A A Knopf.

Grace, Patricia

I986 Potiki. Auckland: Penguin Books.

I993 Cousins. London: The Women's Press. First published by Penguin Books, Auckland (I992).

I998 Baby No-Eyes. Honolulu: University of Hawai'i Press.

Kāretu, Timoti

I994 Tōku Reo, Tōku Mana. In He Whakaatanga o te Ao, vol 2 of Te Ao Mārama, edited by Witi Ihimaera, 222-239. Auckland: Reed.

Keown, Michelle

2007 Pacific Islands Writing: The Postcolonial Literatures of Aotearoal New Zealand and Oceania. Oxford: Oxford University Press. 
Knudsen, Eva Rask

2004 The Circle and the Spiral: A Study of Australian Aboriginal and New Zealand Maori Literature. Amsterdam: Rodopi.

Leys, Ruth 2000 Trauma: A Genealogy. Chicago: The University of Chicago Press.

Luckhurst, Roger 2008 The Trauma Question. London: Routledge.

Marsden, Maori

I992 God, Man and Universe: A Maori View. In Te Ao Hurihuri: Aspects of Maoritanga, edited by Michael King, I I7-I37. Auckland: Reed.

Metge, Joan

I976 Rautahi: The Maoris of New Zealand. Revised edition. London: Routledge \& Kegan Paul. First published in 1967.

Miller, Ana

2008 The Past in the Present: Personal and Collective Trauma in Achmat Dangor's Bitter Fruit. Studies in the Novel 40 (I/2): I46-I60.

Mutu, Margaret

20I I Māori Issues. Polynesia in Review: Issues and Events, I July 200930 June 20I0. The Contemporary Pacific 23:227-232.

Najita, Susan Y

2006 Decolonizing Cultures in the Pacific: Reading History and Trauma in Contemporary Fiction. New York: Routledge.

Park Sorensen, Eli

2010 Postcolonial Studies and the Literary: Theory, Interpretation and the Novel. Basingstoke, Uk: Palgrave Macmillan.

Patterson, John

I992 Exploring Maori Values. Palmerston North, NZ: The Dunmore Press. Prentice, Chris

2009 From Visibility to Visuality: Patricia Grace's Baby No-Eyes and the Cultural Politics of Decolonization. Modern Fiction Studies 55 (2): $32 \mathrm{I}-348$.

Romaine, Suzanne

2004 Contested Visions of History in Aotearoa New Zealand Literature: Witi Ihimaera's The Matriarch. The Contemporary Pacific I6:3 I57 .

Rothberg, Michael

2008 Decolonizing Trauma Studies: A Response. Studies in the Novel 40 (I/2): 224-234.

Smith, Linda Tuhiwai

I993 Māori Education-A Reassertion (extract). In He Whakaatanga o te Ao, vol 2 of Te Ao Mārama, edited by Witi Ihimaera, 218-222. Auckland: Reed. 
I999 Decolonizing Methodologies: Research and Indigenous Peoples. Dunedin, NZ: University of Otago Press.

Toremans, Tom

2003 Trauma: Theory-Reading (and) Literary Theory in the Wake of Trauma. European Journal of English Studies 7 (3): 333-35 I.

Visser, Irene

20I I Trauma Theory and Postcolonial Literary Studies. The Journal of

Waitangi Tribunal Postcolonial Writing 47 (3): 270-282.

I986 Report of the Waitangi Tribunal on the Te Reo Māori Claim. Available via Waitangi Tribunal website: http://www.waitangi-tribunal

Walker, Holly .govt.nz/reports

2005 Developing Difference. Kunapipi: Journal of Postcolonial Writing 27

Walker, Ranginui (2): 2 I 5-230.

I992 Marae: A Place to Stand. In Te Ao Huriburi: Aspects of Maoritanga, edited by Michael King, I 5-27. Auckland: Reed.

2004 Struggle Without End: Ka Whawhai Tonu Matou. Auckland: Penguin.

Whitehead, Anne

2008 Journeying through Hell: Wole Soyinka, Trauma, and Postcolonial Nigeria. Studies in the Novel 40 (I/2): I3-30.

\section{Abstract}

Postcolonial literary critics today increasingly draw on cultural trauma theory to illuminate processes concerning the traumatic aftermath of colonization. There is also, however, a growing resistance to some of cultural trauma theory's central concepts and its basic orientation, which are often deemed inadequate for the interpretation of postcolonial literatures. This article aims to contribute to this discussion as well as to contribute to a critical understanding of Patricia Grace's fiction-or more precisely, of the aftermath of colonial repression that is represented in her novels of the I980s and I990s as an invidious and in fact traumatic "goodness." The fictional dramatization of the trauma of "goodness" in the settings of school, orphanage, and hospital foregrounds a paradox that is central to Grace's depiction of the lives of Māori children in the second half of the twentieth century, when the colonial contradictions between education and repression, care and wounding were still making themselves felt. Grace's emphasis is on the long-lasting psychological imprint of colonial repression in primary schools, as 
institutes of care and instruction, where the concept of goodness is contaminated to the extent that it becomes indistinguishable from evil. In exploring this traumatic "goodness" as a colonizing concept in Grace's fiction, this article reflects on the expository potential of trauma theory and on its limitations for postcolonial critical praxis.

KEYwords: Aotearoa/New Zealand, Māori literature, Patricia Grace, goodness, cultural trauma theory, orality 